\title{
Sustainability concern of housing: emergy storage and flow assessment
}

\author{
R. M. Pulselli, F. M. Pulselli, N. Marchettini \& S. Bastianoni \\ Department of Chemical and Biosystems Sciences, University of Siena, \\ Italy
}

Abstract

A city is an organized open structure made of assembled materials and buildings that constantly interface with changeable contextual agents such as clime, weather, solar irradiation and human beings. Urban systems feed on energy inflows in order to achieve an organization (e.g. society, economy, architecture) that is maintained in time. The interaction of different inputs from the environment generates the building as a built storage in which energy and materials have been stocked. Energy and materials inflows are required to maintain and to use the building in time (for instance, electricity, water and gas are needed for building use). These interaction processes between buildings and the external environment are the focus of this study.

Is it possible to measure these processes to evaluate sustainability of urban systems? How can the impact due to resource exploitation of housing on local sustainability be measured? Can we evaluate the environmental effects of urban strategies and structural plans?

An environmental accounting method, namely emergy analysis (spelled with an ' $m$ '), was applied to an urban area considering the main activities of an entire human settlement and a detailed analysis was focussed on housing: the general environmental performances of buildings in terms of resource exploitation were evaluated considering their construction, maintenance and use.

As a case study, an emergy analysis of the municipality of Ravenna (north-eastern Italy) is presented with a special focus on housing and on the trend of growth of the building industry.

Keywords: emergy analysis, housing, buildings, neighbourhoods, urban systems, dissipative structures. 


\section{A thermodynamic approach to urban systems}

An urban system can be conceived as an ecosystem in which there is a continuous interaction between a community of organisms (mainly humans) and the physical environment, whether it was natural or man-made, as once Eugene Odum [1] affirmed: "[an ecosystem] is a unit of biological organization made up of all of the organisms in a given area interacting with the physical environment". In urban regions, many interacting living agents coexist and a physical structure, made of lands, nature, buildings, infrastructures, technologies and other settings, is combined with a social community. This conjunction of non-living things with living agents let cities belong the category of ecosystems.

According to Francis Evans [2]: "in its fundamental aspects, an ecosystem involves the circulation, transformation, and accumulation of energy and matter through the medium of living things and their activities". Similarly, urban systems require inflows of energy and materials for self-maintenance.

Urban regions therefore 1) are extremely energy intensive; 2) require large inputs of energy and materials from the external environment 3) produce copious amounts of waste; 4) are human-dominated systems.

Eugene Odum [3] has further argued that an integral part of the ecosystem concept is a model of an open, thermodynamic non-equilibrium system, with the emphasis on the external environment. In urban regions, an organization (e.g. society, economy, architecture) is achieved and maintained over time. In other words, according to non-equilibrium thermodynamics, urban regions feed on different kinds of resources, whether locally available or imported from outside, that keep them in a steady state, that is a state far from thermodynamic equilibrium [4].

Ilya Prigogine introduced the concept of dissipative structure that can be considered to describe the general behaviour of human systems in urban regions, with their population, activities and settings. According to Prigogine, dissipative structures are defined as thermodynamic non equilibrium systems open to both energy and matter that self-organize towards high levels of complexity and organization (Prigogine and Stengers [5]). Therefore, dissipative structures are open living systems, far from thermodynamic equilibrium, able to self-maintain in a steady state (dynamicity, diversity, life) at high levels of organization; they constantly exchange energy and matter with the external environment, structuring themselves and evolving on the basis of these interactions.

An urban system, like a dissipative structure, absorbs high quality fluxes of energy and materials from the outside to self-organize; in terms of entropy, this means that it tends towards a state of minimum entropy (Tiezzi $[6,7]$ ).

\section{Introduction to the emergy analysis}

Emergy analysis (spelled with an "m") is an environmental accounting method that develops an energy systems language for the thermodynamics of open systems (Odum and Odum [8]; Odum [9]). When applied to a building, it is processed to quantify all the environmental resources used for building manufacturing, maintenance and use. 
For definition, emergy is the available solar energy previously used up, directly and indirectly, to make a service or product (Odum [9-11]). The emergy evaluation assigns a value to products and services by converting them into equivalents of one form of energy, the solar energy, that is used as the common denominator through which different types of resources, either energy or matter, can be measured and compared to each other. The unit for emergy is the solar emergy joule ( $s e j)$.

The emergy of different products is assessed by multiplying mass quantities $(\mathrm{kg})$ or energy quantities (Joule) by a transformation coefficient, namely transformity or specific emergy. Transformity is the solar emergy required, directly or indirectly, to make one Joule or kilogram of a product or service. Every time a process is evaluated, previously calculated transformities are used as a practical way of determining the emergy (sej) of commonly used products or services.

By definition, the solar emergy $B_{k}$ of the flow $k$ coming from a given process, for example housing, including the processes of building manufacturing, maintenance and use, is:

$$
\mathrm{B}_{\mathrm{k}}=\Sigma_{\mathrm{i}} \operatorname{Tr}_{\mathrm{i}} \mathrm{E}_{\mathrm{i}} \quad \mathrm{i}=1, \ldots, \mathrm{n}
$$

where $E_{i}$ is the actual energy content of the $\mathrm{i}$-th independent input flow to the process, (e.g. materials, human work, solar irradiation, etc.) and $\mathrm{Tr}_{\mathrm{i}}$ is the solar transformity of the i-th input flow.

In this paper an emergy analysis of buildings is presented with special reference to a published work (Pulselli et al. [12]) in which an emergy analysis was applied to a specific case study. Results are here expressed in a more general form and then applied to an entire urban region. The emergy of housing presented here refers to the municipality of Ravenna, in north-eastern Italy. An emergy analysis of the urban system of Ravenna as a whole was also published in Pulselli et al. [13] and used as a basic reference for comparing outcomes.

\section{Emergy analysis of buildings}

Referring to Pulselli et al. [12], an emergy analysis of housing is here developed in order to give a comprehensive evaluation of a traditional contemporary building. Outcomes refer to a traditional building block (usually in south Europe) with a reinforced concrete frame and brick walls. Results were processed in terms of emergy per unit of built volume $\left(\mathrm{sej} / \mathrm{m}^{3}\right)$ as a sort of specific emergy of buildings.

In Figure 1 an energy system diagram of a building is shown with inflows of energy and materials. In the diagram: the building is shown as a built stock (symbol of storage) that, once manufactured, is maintained in time (ordinary maintenance). More in detail, the analysis was based on three distinguished processes: 1) building manufacturing; 2) building use; 3 ) building maintenance.

The interaction of different inputs, such as soil, water, energy, machinery, human work, materials, transport and other services (energy and materials flows) 
generates the building as a built storage in which energy and materials have been stocked. Also a flow of energy and materials is used for the ordinary maintenance of the building in time. In the analysis this flow is assumed to be constant for 50 years that is the likely building lifetime. Building use is then shown by a rectangle. In this phase, inflows of energy for cooling and heating, electricity, gas and water are constantly needed.

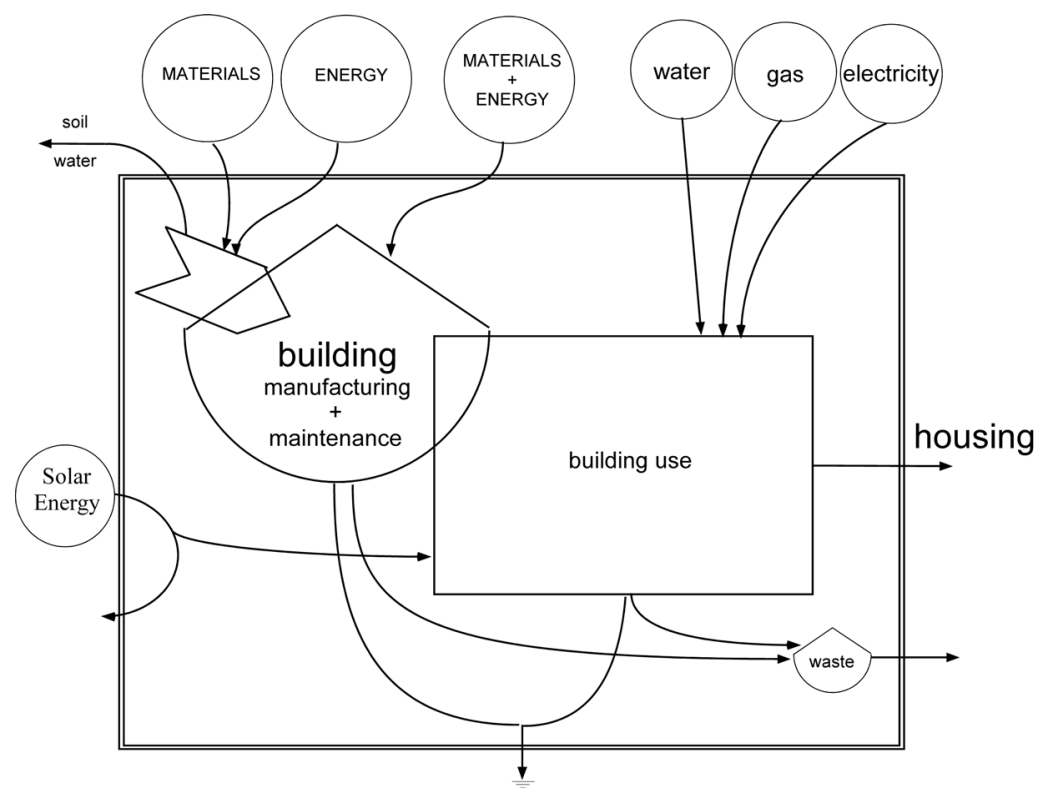

Figure 1: $\quad$ Energy system diagram of a building.

All the inputs to the process are then assessed by collecting and processing data as shown in Table 1. Every raw data (mass quantities) in the building metric computation was allocated to a unit of built volume $\left(\mathrm{m}^{3}\right)$ and expressed in terms of equivalent solar emergy (sej) through the transformity. Emergy flows refer to the quantity of materials used per $\mathrm{m}^{3}$ of building and human work, soil erosion and solar irradiation for building manufacturing. Emergy of manufacturing per built $\mathrm{m}^{3}$ represents the amount of environmental resources stoked in the building as a storage.

The emergy for building maintenance was assessed considering the quantity of energy and materials that are needed to maintain buildings, that is to maintain the emergy stocked in the built storage constant in time, contrasting the entropic degradation. Maintenance is therefore an annual inflow to the building. An emergy assessment of building maintenance was presented considering a 50 years average lifetime of buildings.

Results highlight the 'environmental cost' in terms of sej of building materials that is about $65 \%$ of the entire process of building manufacturing and maintenance (50 years). Transformities used are available in literature and were 
accounted for each material considering the production processes from the origin to the provision (i.e. from the extraction of raw materials, to the final product). The emergy of building materials in a built $\mathrm{m}^{3}$ are therefore expressed through emergy as a combination of used quantity $\left(\mathrm{kg} / \mathrm{m}^{3}\right)$ and environmental cost $(\mathrm{sej} / \mathrm{kg})$. Results highlight the high impact due to concrete in contemporary architecture.

Table 1: $\quad$ Emergy of building manufacturing and maintenance: sej per built $\mathrm{m}^{3}$.

\begin{tabular}{lcccc}
\hline RAW DATA & $\begin{array}{c}\text { Composition } \\
\left(\mathbf{k g} / \mathbf{m}^{\mathbf{3}} \mathbf{)}\right.\end{array}$ & $\begin{array}{c}\text { Specific } \\
\text { Emergy } \\
\mathbf{( s e j / k g )}\end{array}$ & $\begin{array}{c}\text { Emergy } \\
\mathbf{( s e j )}\end{array}$ & $\%$ \\
\hline Concrete & 306.81 & $1.79 \mathrm{E}+12$ & $5.49 \mathrm{E}+14$ & $32.48 \%$ \\
Brick and tiles & 76.92 & $3.68 \mathrm{E}+12$ & $2.83 \mathrm{E}+14$ & $16.75 \%$ \\
Mortar & 21.24 & $3.31 \mathrm{E}+12$ & $7.03 \mathrm{E}+13$ & $4.16 \%$ \\
Steel & 7.72 & $6.97 \mathrm{E}+12$ & $5.39 \mathrm{E}+13$ & $3.19 \%$ \\
Stony materials & 18.53 & $2.44 \mathrm{E}+12$ & $4.52 \mathrm{E}+13$ & $2.68 \%$ \\
Plaster & 11.50 & $3.29 \mathrm{E}+12$ & $3.79 \mathrm{E}+13$ & $2.24 \%$ \\
Paint & 1.14 & $2.55 \mathrm{E}+13$ & $2.91 \mathrm{E}+13$ & $1.72 \%$ \\
Copper & 0.09 & $1.04 \mathrm{E}+14$ & $9.20 \mathrm{E}+12$ & $0.54 \%$ \\
Polystyrene & 1.03 & $8.85 \mathrm{E}+12$ & $9.07 \mathrm{E}+12$ & $0.54 \%$ \\
PVC & 0.58 & $9.86 \mathrm{E}+12$ & $5.71 \mathrm{E}+12$ & $0.34 \%$ \\
Aluminium & 0.15 & $2.13 \mathrm{E}+13$ & $3.20 \mathrm{E}+12$ & $0.19 \%$ \\
Wood & 0.49 & $2.40 \mathrm{E}+12$ & $1.17 \mathrm{E}+12$ & $0.07 \%$ \\
Glass & 0.01 & $2.16 \mathrm{E}+12$ & $1.69 \mathrm{E}+10$ & $0.001 \%$ \\
\hline Human work (in jouls) & $1.76 \mathrm{E}+06$ & $1.24 \mathrm{E}+07$ & $2.18 \mathrm{E}+13$ & $1.29 \%$ \\
Land use (in joules) & $3.82 \mathrm{E}+07$ & $1.24 \mathrm{E}+05$ & $4.74 \mathrm{E}+12$ & $0.28 \%$ \\
Solar radiation (in jouls) & $1.50 \mathrm{E}+09$ & $1.00 \mathrm{E}+00$ & $1.50 \mathrm{E}+09$ & $0.0001 \%$ \\
\hline Emergy manufacturing per built $\mathbf{m}^{\mathbf{3}}$ & & $\mathbf{1 . 1 2 E + 1 5}$ & $\mathbf{6 6 . 4 5 \%}$ \\
Maintenance (year) & & set of items & $1.13 \mathrm{E}+13$ & \\
Maintenance (50 years) & & set of items & $\mathbf{5 . 6 7 E + 1 4}$ & $\mathbf{3 3 . 5 5 \%}$ \\
\hline Total Emergy stock per built $\mathbf{m}^{\mathbf{3}}$ & & $\mathbf{1 . 6 9 E + 1 5}$ & $\mathbf{1 0 0 \%}$ \\
\hline
\end{tabular}

In Table 2, consumptions of electricity, gas and water are presented per year (as an annual inflow) and during the entire building lifetime (assumed around 50 years). These emergy flows are due to building use.

Results were obtained for the processes of building manufacturing, maintenance and use; they show the following values:

- The emergy of building manufacturing is $1.12 \times 10^{15}$ sej per $\mathrm{m}^{3}$. It represents the investment in terms of natural capital to provide the building. This amount of emergy could be conceived as emergy stocked in the building. As shown in the energy system diagram buildings are 
emergy storages. This emergy investment is made once in the entire building lifetime.

- Emergy of building maintenance is $1.13 \times 10^{13} \mathrm{sej} / \mathrm{yr}$ per $\mathrm{m}^{3}$. This flow is spent to maintain the building emergy stock. This is an annual emergy flow.

- The total emergy flow due to building use is $6.71 \times 10^{12} \mathrm{sej} / \mathrm{yr}$ per $\mathrm{m}^{3}$. This is an annual emergy flow.

Table 2: $\quad$ Emergy of building use: specific emergy per built $\mathrm{m}^{3}$.

\begin{tabular}{lccccc}
\hline RESOURCE USE & Quant./m & Unit & $\begin{array}{c}\text { Transformity } \\
\text { (Sej/unit) }\end{array}$ & $\begin{array}{c}\text { Emergy } \\
\text { (Sej/yr) }\end{array}$ & $\begin{array}{c}\text { Emergy (Sej) } \\
\text { per 50 years }\end{array}$ \\
\hline Electric Energy & $3.09 \mathrm{E}+07$ & $\mathrm{~J} / \mathrm{yr}$ & $2.07 \mathrm{E}+05$ & $\mathbf{6 . 4 0 E + 1 2}$ & $3.20 \mathrm{E}+14$ \\
Gas Heating & $8.22 \mathrm{E}+04$ & $\mathrm{~J} / \mathrm{yr}$ & $6.72 \mathrm{E}+04$ & $\mathbf{5 . 5 2 E}+\mathbf{0 9}$ & $2.76 \mathrm{E}+11$ \\
Water Supply & $1.58 \mathrm{E}+02$ & $\mathrm{~kg} / \mathrm{yr}$ & $1.95 \mathrm{E}+09$ & $\mathbf{3 . 0 9 E}+\mathbf{1 1}$ & $1.54 \mathrm{E}+13$ \\
\hline Total emergy for building use per built $\mathbf{~ m}^{\mathbf{3}}$ & & $\mathbf{6 . 7 1 E + 1 2}$ & $3.35 \mathrm{E}+14$ \\
\hline
\end{tabular}

\section{Emergy analysis of urban systems: the case of Ravenna}

An emergy analysis was applied to the urban system of Ravenna as a whole and published in Pulselli et al. [13]. When applied to a region, many inputs to a multiplicity of processes are taken into account in order to give a measure of different activities and processes that take place in a local area. In the case of Ravenna, we assessed energy and materials inflows relative to physical aspects, energy consumption, materials use, fuel combustion, agriculture and industry, as shown in Table 3. Data and results refer to the year 2003.

The area under study is about $653 \mathrm{~km}^{2}$ with a population of 141,800 persons (equivalent to a density of 217 persons $/ \mathrm{km}^{2}$ ). It is a highly industrialized area and relevant amounts of natural gas are also used for a local thermoelectricity production (electricity is also exported to the outside). This industrial vocation is thus highlighted by high emergy values of industry $\left(1.44 \times 10^{22} \mathrm{sej}\right)$. Also a high value of emergy is due to natural gas $\left(9.30 \times 10^{20}\right.$ sej) that is used for thermoelectricity production, besides industry and housing. For this reason, electricity consumption was not accounted in order to avoid a double counting. Solar irradiation and wind were accounted in the emergy of rain because they are co-products of solar energy.

The total used emergy of the municipality of Ravenna, in 2003 , was $2.80 \times 10^{22}$ sej.

\section{Emergy analysis of housing}

In the municipality of Ravenna, there were 78,745 houses in 2001 (distributed into 28,960 buildings for housing), each of $94.02 \mathrm{~m}^{2}$ average, and $44.14 \mathrm{~m}^{2}$ per person (ISTAT [14]).

In Table 4, the number of houses and relative square meters and volume, in the municipality of Ravenna, are reported with the equivalent amount of emergy for building manufacturing, use and maintenance. Values refer to the years 2001 and 2003. 
Table 3: Emergy analysis of an urban system: the municipality of Ravenna, 2003.

\begin{tabular}{|c|c|c|c|c|}
\hline Input & Quantity & Unit/yr & $\begin{array}{c}\text { Specific Emergy } \\
\text { (sej/unit) }\end{array}$ & $\begin{array}{l}\text { Emergy } \\
\text { (sej/yr) }\end{array}$ \\
\hline PHYSICAL AGENTS & & & & $9.11 \mathrm{E}+19$ \\
\hline 1 Solar irradiation (already accounted as rain) & $2.33 \mathrm{E}+18$ & $\mathrm{~J}$ & $1.00 \mathrm{E}+00$ & $2.33 \mathrm{E}+18$ \\
\hline 2 Rain & $4.15 \mathrm{E}+14$ & g & $1.45 \mathrm{E}+05$ & $6.01 \mathrm{E}+19$ \\
\hline 3 Wind (already accounted as rain) & $1.24 \mathrm{E}+15$ & $\mathrm{~J}$ & $2.45 \mathrm{E}+03$ & $3.03 E+18$ \\
\hline 4 Geothermal heat & $6.86 \mathrm{E}+14$ & $\mathrm{~J}$ & $1.20 \mathrm{E}+04$ & $8.24 \mathrm{E}+18$ \\
\hline 5 Soil erosion & $1.83 \mathrm{E}+14$ & $\mathrm{~J}$ & $1.24 \mathrm{E}+05$ & $2.28 \mathrm{E}+19$ \\
\hline WATER AND ENERGY & & & & $9.62 \mathrm{E}+20$ \\
\hline 6 Water use & $1.61 \mathrm{E}+13$ & g & $1.95 \mathrm{E}+06$ & $3.13 \mathrm{E}+19$ \\
\hline 7 Natural gas & $1.15 \mathrm{E}+16$ & $\mathrm{~J}$ & $8.11 \mathrm{E}+04$ & $9.30 \mathrm{E}+20$ \\
\hline 8 Electricity use (already accounted as natural gas) & $1.88 \mathrm{E}+15$ & $\mathrm{~J}$ & $2.05 \mathrm{E}+05$ & $3.85 \mathrm{E}+20$ \\
\hline MATERIALS & & & & $1.64 \mathrm{E}+21$ \\
\hline 9 Extracted materials (sand and and gravel) & $9.78 \mathrm{E}+11$ & g & $1.68 \mathrm{E}+09$ & $1.64 \mathrm{E}+21$ \\
\hline FUELS & & & & $5.41 \mathrm{E}+21$ \\
\hline 10 Gasoline and diesel & $7.25 \mathrm{E}+15$ & $\mathrm{~J}$ & $1.11 \mathrm{E}+05$ & $8.05 \mathrm{E}+20$ \\
\hline 11 Fuel oil and GPL & $5.05 \mathrm{E}+16$ & $\mathrm{~J}$ & $9.12 \mathrm{E}+04$ & $4.60 \mathrm{E}+21$ \\
\hline $\begin{array}{l}\text { AGRICULTURE AND ANIMALS } \\
\text {. }\end{array}$ & & & & $5.22 \mathrm{E}+21$ \\
\hline 12 Cereals & $1.05 \mathrm{E}+16$ & $\mathrm{~J}$ & $2.67 \mathrm{E}+05$ & $2.81 \mathrm{E}+21$ \\
\hline 13 Legumes & $5.04 \mathrm{E}+14$ & $\mathrm{~J}$ & $1.75 \mathrm{E}+05$ & $8.82 E+19$ \\
\hline 14 Fruit & $1.53 \mathrm{E}+14$ & $\mathrm{~J}$ & $4.82 \mathrm{E}+05$ & $7.37 \mathrm{E}+19$ \\
\hline 15 Vegetables & $3.38 \mathrm{E}+12$ & J & $7.38 \mathrm{E}+05$ & $2.49 \mathrm{E}+18$ \\
\hline 16 Seeds & $1.36 \mathrm{E}+15$ & J & $1.33 \mathrm{E}+06$ & $1.81 \mathrm{E}+21$ \\
\hline 17 Spices & $6.00 \mathrm{E}+12$ & J & $1.75 \mathrm{E}+05$ & $1.05 \mathrm{E}+18$ \\
\hline 18 Flowers & $4.26 \mathrm{E}+10$ & g & $4.74 \mathrm{E}+09$ & $2.02 \mathrm{E}+20$ \\
\hline 19 Cuttle breeding & $1.13 \mathrm{E}+13$ & $\mathrm{~J}$ & $5.33 \mathrm{E}+06$ & $6.03 E+19$ \\
\hline 20 Forestry & $5.70 \mathrm{E}+08$ & g & $1.68 \mathrm{E}+08$ & $9.58 \mathrm{E}+16$ \\
\hline 21 Fishing and hunting & $7.31 \mathrm{E}+11$ & $\mathrm{~g}$ & $2.27 \mathrm{E}+08$ & $1.66 \mathrm{E}+20$ \\
\hline EXTRACTIVE INDUSTRY & & & & $6.60 \mathrm{E}+20$ \\
\hline 22 Extractive industry (metal minerals) & $1.31 \mathrm{E}+11$ & g & $1.68 \mathrm{E}+09$ & $2.19 \mathrm{E}+20$ \\
\hline 23 Extractive industry (non metal minerals) & $2.62 \mathrm{E}+11$ & g & $1.68 \mathrm{E}+09$ & $4.41 \mathrm{E}+20$ \\
\hline INDUSTRY & & & & $1.40 \mathrm{E}+22$ \\
\hline 24 Food industry & $6.05 \mathrm{E}+11$ & g & $2.52 \mathrm{E}+09$ & $1.52 \mathrm{E}+21$ \\
\hline 25 Tobacco industry & $1.06 \mathrm{E}+07$ & $\mathrm{~J}$ & $1.75 \mathrm{E}+05$ & $1.85 \mathrm{E}+12$ \\
\hline 26 Leather industry & $3.87 \mathrm{E}+12$ & $\mathrm{~J}$ & $1.44 \mathrm{E}+07$ & $5.57 \mathrm{E}+19$ \\
\hline 27 Textile industry & $9.89 \mathrm{E}+12$ & $\mathrm{~J}$ & $6.38 \mathrm{E}+06$ & $6.31 \mathrm{E}+19$ \\
\hline 28 Furniture and clothing industry & $7.86 \mathrm{E}+12$ & $\mathrm{~J}$ & $6.38 \mathrm{E}+06$ & $5.01 \mathrm{E}+19$ \\
\hline 29 Wood and cork industry & $5.87 \mathrm{E}+10$ & g & $6.79 \mathrm{E}+08$ & $3.98 \mathrm{E}+19$ \\
\hline 30 Paper industry & $5.57 \mathrm{E}+15$ & J & $3.61 \mathrm{E}+05$ & $2.01 \mathrm{E}+21$ \\
\hline 31 Graphic industry & $1.17 \mathrm{E}+14$ & $\mathrm{~J}$ & $3.61 \mathrm{E}+05$ & $4.23 \mathrm{E}+19$ \\
\hline 32 Metallurgic industry & $1.05 \mathrm{E}+12$ & g & $5.81 \mathrm{E}+09$ & $6.10 \mathrm{E}+21$ \\
\hline 33 Mechanical industry & $1.27 \mathrm{E}+10$ & g & $1.13 \mathrm{E}+10$ & $1.43 \mathrm{E}+20$ \\
\hline 34 Mineral industry & $1.71 \mathrm{E}+11$ & g & $1.68 \mathrm{E}+09$ & $2.86 \mathrm{E}+20$ \\
\hline 35 Chemical industry & $5.76 \mathrm{E}+12$ & g & $6.38 \mathrm{E}+08$ & $3.67 \mathrm{E}+21$ \\
\hline 36 Rubber industry & $1.88 \mathrm{E}+09$ & g & $6.42 \mathrm{E}+09$ & $1.20 \mathrm{E}+19$ \\
\hline 37 Other manufacturing industries & $5.04 \mathrm{E}+09$ & g & $5.81 \mathrm{E}+09$ & $2.93 \mathrm{E}+19$ \\
\hline TOTAL USED EMERGY & & & & $2.80 \mathrm{E}+22$ \\
\hline
\end{tabular}

Table 4: $\quad$ Emergy storage of housing in the municipality of Ravenna.

\begin{tabular}{ccccccc}
\hline Up to year & Total houses & $\mathbf{m}^{2}$ & $\mathbf{m}^{\mathbf{3}}$ & $\begin{array}{c}\text { emergy } \\
\text { building } \\
\text { manufact. }\end{array}$ & $\begin{array}{c}\text { emergy } \\
\text { building } \\
\text { use }\end{array}$ & $\begin{array}{c}\text { emergy } \\
\text { building } \\
\text { mainten. }\end{array}$ \\
\hline 2001 & 78,745 & $7,403,605$ & $22,210,815$ & $2.49 \mathrm{E}+22$ & $1.49 \mathrm{E}+20$ & $2.52 \mathrm{E}+20$ \\
2003 & 80,204 & $7,557,288$ & $22,671,865$ & $2.55 \mathrm{E}+22$ & $1.52 \mathrm{E}+20$ & $2.57 \mathrm{E}+20$ \\
\hline
\end{tabular}


Table 5: $\quad$ Emergy assessment of new manufactured buildings: time series.

\begin{tabular}{|c|c|c|c|c|c|c|}
\hline Year & houses & $\mathrm{mq}$ & $\mathrm{mc}$ & $\begin{array}{c}\text { emergy } \\
\text { building } \\
\text { manufact. }\end{array}$ & $\begin{array}{c}\text { emergy } \\
\text { building } \\
\text { use }\end{array}$ & $\begin{array}{c}\text { emergy } \\
\text { building } \\
\text { mainten. }\end{array}$ \\
\hline 1991 & 420 & 68,192 & 204,576 & $2.30 \mathrm{E}+20$ & $1.37 \mathrm{E}+18$ & $2.32 \mathrm{E}+18$ \\
\hline 1992 & 513 & 75,327 & 225,981 & $2.54 \mathrm{E}+20$ & $1.52 \mathrm{E}+18$ & $2.56 \mathrm{E}+18$ \\
\hline 1993 & 422 & 71,398 & 214,195 & $2.41 \mathrm{E}+20$ & $1.44 \mathrm{E}+18$ & $2.43 E+18$ \\
\hline 1994 & 458 & 70,719 & 212,157 & $2.38 \mathrm{E}+20$ & $1.42 \mathrm{E}+18$ & $2.41 \mathrm{E}+18$ \\
\hline 1995 & 378 & 37,906 & 113,718 & $1.28 \mathrm{E}+20$ & $7.63 E+17$ & $1.29 \mathrm{E}+18$ \\
\hline 1996 & 308 & 44,615 & 133,844 & $1.50 \mathrm{E}+20$ & $8.98 \mathrm{E}+17$ & $1.52 E+18$ \\
\hline 1997 & 740 & 90,503 & 271,516 & $3.05 \mathrm{E}+20$ & $1.82 \mathrm{E}+18$ & $3.08 E+18$ \\
\hline 1998 & 552 & 61,073 & 183,218 & $2.06 \mathrm{E}+20$ & $1.23 E+18$ & $2.08 \mathrm{E}+18$ \\
\hline 1999 & 873 & 108,389 & 325,166 & $3.65 \mathrm{E}+20$ & $2.18 \mathrm{E}+18$ & $3.69 E+18$ \\
\hline 2000 & 654 & 89,222 & 267,668 & $3.01 \mathrm{E}+20$ & $1.80 \mathrm{E}+18$ & $3.04 E+18$ \\
\hline 2001 & 550 & 72,431 & 217,293 & $2.44 \mathrm{E}+20$ & $1.46 \mathrm{E}+18$ & $2.46 \mathrm{E}+18$ \\
\hline 2002 & 592 & 66,835 & 200,505 & $2.25 \mathrm{E}+20$ & $1.35 E+18$ & $2.27 E+18$ \\
\hline 2003 & 867 & 86,848 & 260,545 & $2.93 \mathrm{E}+20$ & $1.75 \mathrm{E}+18$ & $2.95 \mathrm{E}+18$ \\
\hline $\begin{array}{l}\text { average } \\
\text { per year }\end{array}$ & 564 & 72,574 & 217,722 & $45 \mathrm{E}+20$ & -18 & 18 \\
\hline
\end{tabular}

The emergy amount for building manufacturing is an evaluation of the investment of environmental resources used for construction and thus maintained in buildings as in an emergy storage. The built environment is thus a storage of emergy equivalent to $2.55 \times 10^{22}$ sej, up to 2003 , that has been previously spent to provide the urban architecture.

The emergy amount for building maintenance $\left(2.57 \times 10^{20} \mathrm{sej}\right)$ is an annual emergy flow as well as the emergy for building use $\left(1.52 \times 10^{20}\right.$ sej) given by assessing water, natural gas and electricity consumption. These values refer to the annual emergy flow needed to supply and use the whole of buildings in the municipality of Ravenna.

In Table 5, a time series of the building industry is shown since 1991 to 2003. An average value (13 years database) is given in the last raw. The built environment grew with a rate of $217,722 \mathrm{~m}^{3} / \mathrm{yr}$ that corresponds to an increase of equivalent $2.45 \times 10^{20} \mathrm{sej} / \mathrm{yr}$ for building manufacturing; an emergy flow of $1.46 \times 10^{18} \mathrm{sej} / \mathrm{yr}$ and $2.47 \times 10^{18} \mathrm{sej} / \mathrm{yr}$ due to the new buildings has to be added to the annual cost for building use and maintenance respectively.

\section{Conclusion}

This paper presents new outcomes from the emergy assessment of building manufacturing, use and maintenance extending results from the case study of a specific building (as presented in Pulselli et al. [12]), more in general, to a traditional typology, a building block with a reinforced concrete frame and brick walls. Thus, emergy values for building construction, use and maintenance were allocated to a built cube metre as a sort of specific emergy of buildings in order to provide an emergy assessment of housing of an entire neighbourhood or urban area. An emergy evaluation of housing (and the building industry) in the municipality of Ravenna was achieved by comparing results with the emergy analysis of the entire territorial system (referring to: Pulselli et al. [13]), with its 
physical agents, population, consumption, agriculture, industry and other activities. In particular, emergy of building construction, that refers to the resource use of the building industry, was compared to other human activities, in the local area in order to measure the environmental concern of housing.

In 2003 , building manufacturing $\left(2.93 \times 10^{20} \mathrm{sej}\right)$ was about $1 \%$ of the total used emergy $\left(2.80 \times 10^{22} \mathrm{sej}\right)$ of Ravenna. The building industry $\left(5.50 \times 10^{20} \mathrm{sej}\right)$ that involves the construction of new buildings $\left(2.93 \times 10^{20}\right.$ sej) and the maintenance $\left(2.57 \times 10^{20} \mathrm{sej}\right)$ of the existing ones is about $4 \%$ of the total emergy of industry.

Building use $\left(1.52 \times 10^{20} \mathrm{sej}\right)$ - water, electricity and natural gas - was about $16 \%$ of the emergy for water, electricity and natural gas assessed for the entire urban region.

The entire building cubature in an urban area always increases due to new buildings. New buildings need resources for manufacturing (especially non renewable) and an increase of resource use of the local community for building maintenance and use (the rate of increasing of the building volume is about $1.2 \% / \mathrm{yr}$ ). Since the growth of built areas is unsustainable and an environmental policy of housing is strongly required, restoring and converting existing buildings is a good practice that needs minor investment of resources. The emergy analysis of housing can be a powerful tool for the evaluation of urban planning practices and making choices. For instance, it suggests restoring existing urban structures and dismissed built areas instead of planning new buildings and neighbourhoods; it measures material and energy saving through the restoration of existing buildings instead of manufacturing new ones. Furthermore, emergy analysis of housing can evaluate the energetic performances of buildings by assessing emergy for building use and an energy saving due to practices of eco-architecture can be assessed and measured for an entire neighbourhood (think, for example to the Bed Zed neighbourhood in London). These and other practices for decreasing the environmental impact of cities can be measured through the emergy analysis of housing.

Results presented above were probably expected to be higher but the area of Ravenna presents intensive industrial activities that have a high impact in terms of emergy use with respect to buildings. In the future, the emergy assessment of housing will be applied to other areas in order to compare new outcomes with the case study presented here.

\section{References}

[1] Odum E., The strategy of ecosystem development, Science, 164, 262-270, 1969.

[2] Evans, F.C., Ecosystem as the basic unit in ecology. Science, 23, $1127-$ $1128,1956$.

[3] Odum, E., Ecology and our endangered life-support systems. Sinauer, Sunderland, Massachusetts, USA, 1989.

[4] Pulselli R.M., Ratti C., Tiezzi E., City out of chaos: social patterns and organization in urban systems, International Journal of Ecodynamics, 1(2), 125-134, 2006. 
[5] Prigogine I. \& Stengers I., La Nouvelle Alliance, Gallimard: Paris, 1979.

[6] Tiezzi E., The Essence of Time, WIT press: Southampton, 2003.

[7] Tiezzi E., Steps Towards an Evolutionary Physics, WIT press: Southampton, 2006.

[8] Odum H. T. \& Odum E.C., Energy basis for man and nature. McGraw Hill: London, 1981

[9] Odum H. T., Environmental accounting: emergy and environmental decision making. Chichester Wiley: New York, 1996

[10] Odum H.T., Environment, power and society. Wiley, New York, US, 1971.

[11] Odum H.T., Systems ecology. Wiley, New York, US, 1983.

[12] Pulselli F.M., Pulselli R.M., Simoncini E., Environmental accounting of buildings: outcomes from the emergy analysis, (Eds.) Mander U., Brebbia C.A., Tiezzi E., The Sustainable City IV, Urban Regeneration and Sustainability. WIT Press, 489-498, 2006.

[13] Pulselli R.M., Magnoli G.C., Tiezzi E.B.P., Emergy flows and sustainable indicators: the Strategic Environmental Assessment for a Master Plan, (Eds.) Marchettini N., Brebbia C.A., Tiezzi E., Wadhwa L.C., The Sustainable City III, Urban Regeneration and Sustainability. WIT Press, 3-10, 2004.

[14] ISTAT 2001. Available on: www.istat.it 